\title{
Influence of grinding zones on the tooth root bending strength of case carburized gears
}

\section{Conference Proceedings}

\author{
Karl Jakob Winkler ${ }^{1}$ (D) Thomas Tobie $^{1} \cdot$ Karsten Stahl $^{1}$
}

Received: 20 May 2021 / Accepted: 7 July 2021 / Published online: 15 September 2021

(c) The Author(s) 2021

\begin{abstract}
Knowledge of the expected tooth root bending strength plays a decisive role in the design of gear sets. Due to dimensional and shape changes resulting from distortion due to the heat treatment, unintentional, partial grinding in the tooth root area may occur, particularly in the application range of large gears. The influences of an unintentional grinding zone on the tooth root bending strength have not yet been clarified with sufficient accuracy. As a result, grinding zones lead to uncertainties when evaluating the tooth root bending strength and thus to a loss of time and cost in the field of industrial practice.

This paper presents experimental investigations on the influence of grinding zones on the tooth root bending strength of case carburized gears. For the experimental investigations, there are three unground reference variants with different blasting treatments: non-blasted, mechanical cleaned by shot blasting and shot peened. The unground reference variants are examined regarding their tooth root bending strength. For the other test gear variants, different grindings zones are applied resulting in light and strong material removal by grinding. The variants with the different grinding zones are examined analogously regarding their tooth root bending strength and are subsequently compared to the reference variants.

The results of the experimental investigations show that grinding zones can have diverse influences on the tooth root bending strength of case carburized gears

- Non-blasted gears do not show changes regarding the tooth root bending strength with regard to light or strong grinding zones applied within this investigation.

- Shot blasted (mechanical cleaned) gears show no change in the tooth root bending strength for light grinding zones (grinding application does not significantly alter the original residual stress state in the tooth root area).

- Shot blasted (mechanical cleaned) gears show a reduction of the tooth bending strength of up to $20 \%$ with regard to strong grinding zones (grinding application does significantly alter the original residual stress state in the tooth root area). - Shot peened gears show a behavior similar to that of shot blasted gears with reductions of the tooth root bending strength of up to $30 \%$.

- Shot peening the strong grinding zones as a repair measure can increase the reduced tooth root bending strength again. However, for the investigated test gears, the resulting tooth root bending strength was below the shot blasted reference variant.

The results of this paper help to evaluate the influence of grinding zones on the tooth root bending strength of case carburized gears more precisely compared to the generalized reductions of current standards and classifications. The results can be incorporated in standards such as DIN 3390 as well as ISO 6336 and can be applied in the field of industrial practice. Eventually, the findings help to reduce the current loss of time and cost caused by uncertainties regarding grinding zones.
\end{abstract}

Karl Jakob Winkler

j.winkler@fzg.mw.tum.de

1 Gear Research Centre (FZG), Technical University of

Munich, Garching near Munich, Germany 


\section{Einfluss von Anschliffen auf die Zahnfußtragfähigkeit einsatzgehärteter Zahnräder}

\section{Zusammenfassung}

Bei der Auslegung von Zahnradgetrieben spielt die Kenntnis der zu erwartenden Zahnfußtragfähigkeit eine entscheidende Rolle. Aufgrund von Maß- und Formänderungen, die aus dem Verzug durch die Wärmebehandlung resultieren, kann es insbesondere im Anwendungsbereich von Zahnrädern großer Baugröße zu einem ungewollten, partiellen Anschleifen im Zahnfußbereich kommen. Die Einflüsse eines ungewollten, angeschliffenen Bereichs auf die Zahnfußtragfähigkeit sind noch nicht mit ausreichender Genauigkeit geklärt. Anschliffe im Zahnfußbereich führen zu Unsicherheiten bei der Bewertung der Zahnfußtragfähigkeit und somit zu einem Zeit- und Kostenverlust in der industriellen Praxis.

In dieser Arbeit werden experimentelle Untersuchungen zum Einfluss von Anschliffen auf die Zahnfußtragfähigkeit von einsatzgehärteten Zahnrädern vorgestellt. Für die experimentellen Untersuchungen stehen drei ungeschliffene Referenzvarianten mit unterschiedlichen Strahlbehandlungen zur Verfügung: ungestrahlt, reinigungsgestrahlt und festigkeitsgestrahlt. Die ungeschliffenen Referenzvarianten werden auf ihre Zahnfußtragfähigkeit untersucht. Bei den anderen Prüfradvarianten werden unterschiedliche Anschliffe aufgebracht, die zu einem leichten und starken Materialabtrag durch Schleifen führen. Die Varianten mit den unterschiedlichen Anschliffen werden analog auf ihre Zahnfußtragfähigkeit untersucht und anschließend mit den Referenzvarianten verglichen.

Die Ergebnisse der experimentellen Untersuchungen zeigen, dass Anschliffe unterschiedliche Einflüsse auf die Zahnfußtragfähigkeit von einsatzgehärteten Zahnrädern haben können:

- Ungestrahlte Zahnräder mit leichten oder starken Anschliffen zeigen in den vorliegenden Untersuchungen keine Veränderungen hinsichtlich der Zahnfußtragfähigkeit.

- Reinigungsgestrahlte Zahnräder zeigen bei leichten Anschliffen keine Veränderung der Zahnfußtragfähigkeit (Anschliff verändert den ursprünglichen Eigenspannungszustand im Zahnfußbereich nicht wesentlich).

- Festigkeitsgestrahlte Zahnräder mit starken Anschliffen zeigen eine Reduzierung der Zahnfußtragfähigkeit von bis zu $20 \%$ (Anschliff verändert den ursprünglichen Eigenspannungszustand im Zahnfußbereich signifikant).

- Festigkeitsgestrahlte Zahnräder zeigen mit Abnahmen der Zahnfußtragfähigkeit von bis zu $30 \%$ ein vergleichbares Verhalten wie die reinigungsgestrahlten Zahnräder.

- Das Festigkeitsstrahlen der starken Anschliffe als Reparaturmaßnahme kann die reduzierte Zahnfußtragfähigkeit wieder erhöhen. Bei den untersuchten Testzahnrädern lag die resultierende Zahnfußtragfähigkeit jedoch unter der reinigungsgestrahlten Referenzvariante.

Die Ergebnisse dieser Arbeit helfen, den Einfluss von Anschliffen auf die Zahnfußtragfähigkeit von einsatzgehärteten Zahnrädern im Vergleich zu den pauschalen Abschlägen aktueller Normen und Klassifikationen genauer zu bewerten. Die Ergebnisse können in Normen wie DIN 3390 sowie ISO 6336 einfließen und in der industriellen Praxis angewendet werden. Letztendlich helfen die Erkenntnisse, den derzeitigen Zeit- und Kostenverlust durch Unsicherheiten bezüglich von Anschliffen zu reduzieren.

\section{Introduction}

\subsection{Usual conditions of tooth root areas in practice}

The typical manufacturing route of the tooth root area of case carburized gears in practice, especially for large sized gears, includes soft-machining using a protuberance cutter, a heat treatment process and a final shot blasting treatment. Usually only the gear flanks are additionally ground. The shot blasting is conducted to mechanically clean the gears after the heat treatment. In addition to cleaning the surfaces, compressive residual stresses are induced by shot blasting in the near surface layer which results in an increased bending strength. For gears with unground and shot-blasted tooth root areas, numerous experiences and test results from research projects as well as from practical applications are available. The characteristic strength values required for the design of gears can be obtained from part 5 of the standards DIN 3990 [4] and ISO 6336 [10]. The characteristic strength values are essentially based on investigations, which were carried out on case-hardened gears whose tooth root area were in an unground and shot-blasted condition.

\subsection{Blasting treatments of the tooth root area}

Apart from being shot blasted, tooth root areas can alternatively be non-blasted or shot peened. According to research by Hirsch [9], shot peening increases the tooth root bending strength by up to $36 \%$ compared to non-blasted gears. Gears with ground tooth root areas are sometimes also shot-peened in industrial practice to introduce beneficial compressive residual stresses and to increase the tooth root bending strength. However, subsequent shot peening is time-consuming and expensive. The already finished tooth 


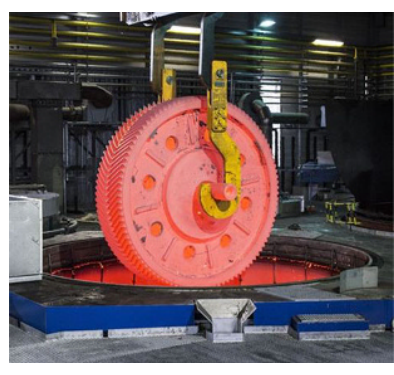

Fig. 1 Case hardening of large gears [8] as root-cause for changes in dimension and shape

flanks usually have to be covered at great expense to avoid an increase of the tooth flank surface roughness due to shot peening.

\subsection{Grinding zones in the tooth root area}

Gears for use in highly loaded transmissions are generally subjected to a heat treatment process in order to meet the high requirements in terms of material strength. To achieve high power densities, most gears are case carburized for many applications. For large gears, as shown in Fig. 1, the heat treatment may lead to particularly large changes in dimension and shape depending on the gear design, the material, and the process parameters. For case-hardened gears, these changes in dimension and shape can lead to undesirable grindings in the tooth root area. The grinding zones are often locally limited and can vary in terms of size, depth and location in the root area. Grinding zones do not reach deep into the material and the amount of material that is grinded off is relatively small. The transition from the tooth root area without grinding towards the grinding zone is smooth and without sharp notches, due to well-rounded grinding discs. Grinding zones are to be distinguished from macroscopic grinding notches. Macroscopic grinding notches are characterized by deeper grindings into the material and result in sharp notches in the tooth root area. Macroscopic grinding notches can be considered in ISO 6336 [10], but are clearly different from the locally limited, grinding zones. The standards DIN 3990 [4] and ISO 6336 [10] give no indication on how to evaluate grinding zones in the tooth root area. Classifications such as DNVGL-CG-0036 [3] indicate a general reduction of the tooth root bending strength by $20 \%$ for gears with grindings in the tooth root area that influence the residual stress state. Up to now, there is a lack of information on the exact extent of the influence of grinding zones on the residual stress state and on the tooth root bending strength.

\section{State of the research}

Part 3 of the standards DIN 3990 [4] and ISO 6336 [10] provide well-established and experienced methods for the cal- culation of the tooth root bending strength of gears. These standards are based on a comparison of the occurring tooth root stress with the permissible tooth root stress. Main influence factors for this comparison are the actual load, the gear geometry and the material strength. Macroscopic grinding notches are known to increase the occurring stress due to the notch effect. As grinding zones are less deep and less sharp, their notch effect is significantly smaller. Besides the stress increasing impact depending on the local geometry of a grinding zone, the following material parameters can additionally be influenced by grinding zones.

\subsection{Residual stresses}

Residual stresses are multiaxial, static stresses acting inside a component that is free from external loads. The internal forces and moments resulting from the residual stresses are in mechanical equilibrium [17]. Residual compressive stresses occurring in the near-surface material layer of the tooth root area can counteract tensile load stresses and thus increase the tooth root bending strength [12, 18, 20]. During case hardening, the heating and subsequent quenching of the component results in a superposition of residual stresses due to the cooling of the material and the transformation of the microstructure [15, 19]. For component heating and cooling processes, residual compressive stresses occur in the surface layer and residual tensile stresses in the core area of the component [2]. Blasting treatments, such as shot blasting or shot peening, introduce additional compressive residual stresses into the component at and near the surface material layer. If the Hertzian pressure, which results from bombarding the surface with the shot media, locally exceeds the yield point in the material, plastic deformation occurs from which residual compressive stresses result [21]. Another cause of residual compressive stresses in hardened components is based on the stress-induced transformation of residual austenite in the near-surface material layer as a result of shot blasting or shot peening. The stress-induced phase transformation from austenite to martensite and the associated increase in volume induce additional residual compressive stresses in the near-surface layer of the material $[6,19]$. When grinding, the surface layer with increased compressive residual stresses due to a blasting treatment is usually completely removed again. Furthermore, the thermal and mechanical energy introduced into the material by the grinding results in a modification of the previously prevailing residual stress state in the near-surface material layer [19]. Depending on whether the converted mechanical or thermal energy portion predominates. compressive as well as tensile residual stresses can occur in the machined components [11]. 


\subsection{Surface roughness}

The surface roughness is a factor influencing the tooth root bending strength. Due to micro-notch effects, the surface roughness leads to local excess stresses, which promote the formation of surface cracks, propagation of cracks and eventually tooth root breakages [7]. By grinding the tooth root area, the surface roughness can be improved while at the same time impairing the original residual stress state.

\subsection{Intergranular oxidation}

Intergranular oxidation is a microstructural degradation in which the alloying elements with a high oxidation potential in the near-surface material layer oxidize with ambient oxygen at high temperatures [14]. For the tooth root bending strength, the linear precipitates along the grain boundaries are considered to be particularly critical, since the risk of intergranular fracture is increased by the oxide-containing and thus brittle grain boundaries [19]. In various fracture mechanics approaches [13, 16, 19], the intergranular oxidation depth is considered as a crack with the same depth.

\section{Aim of investigation}

In the case of grinding operations in the tooth root area, uncertainties and ambiguities exist with regard to the influence on the material properties as well as the tooth root bending strength. The challenges and aims of investigations are listed in the following:

- Gears with most often unintended grinding zones in the tooth root area are often declared as rejects due to uncertainties regarding the tooth root bending strength and thus lead to financial losses. Grinding zones may occur due to changes in dimension and shape caused by the heat treatment, in particular for large size gears. Higher material and manufacturing costs, as well as single part manufacturing, lead to particularly high financial losses when rejects are declared.

- It is assumed, that apart from the notch effect, various material parameters such as the residual stress state, the surface roughness and the intergranular oxidation are influenced by grinding zones. The quality and quantity of the influence of grinding zones with different grinding amounts is yet unclear.

- To restore the residual stress condition, gears with grinding zones can be shot peened, which means an additional production step with a corresponding increase in time and costs. The necessity and effectiveness of shot peening as repair process for gears with grinding zones is yet uncertain.

Overall, it can be stated that uncertainties exist with regard to the influence of grinding zones on the tooth root bending strength. These uncertainties lead to increased rejects, unnecessary repair measures and unused tooth root bending strength potential. This results in a significant increase in time, costs and resources for both manufacturers and users. In order to improve economic efficiency and potential load carrying capacities, the influence of grinding zones is investigated with the aid of experimental tests and measurements.

\section{Test gears and test rig}

\subsection{Test gears}

The test gears have been designed for experimental load carrying capacity investigations on pulsator test rigs. There is an extensive knowledge base available at the research facility concerning these test gears, since the chosen gear geometry has been used in a large number of previous research projects. Table 1 gives an overview of the most important geometry data as well as a geometry draft of the test gear.

Fig. 2 shows the manufacturing route and experimental set-up of the different test gear variants.

All test gears are manufactured out of the same batch of a case-hardening steel 18CrNiMo7-6. The gear cutting of the test gears is carried out with the aid of a hob in protuberance design. All gears are case-carburized in one heat treatment batch with a measured case hardening depth in the root area of $\mathrm{CHD}_{550 \mathrm{HV} 1} \approx 0.14 \cdot \mathrm{m}_{\mathrm{n}}=0.7 \mathrm{~mm}$.

Table 1 Geometry data and geometry draft of the test gear

\begin{tabular}{llll}
\hline Description & Symbol & Unit & Value \\
\hline Normal module & $\mathrm{m}_{\mathrm{n}}$ & $\mathrm{mm}$ & 5 \\
Number of teeth & $\mathrm{z}$ & $-\mathrm{mm}$ & 24 \\
Tooth width & $\mathrm{b}$ & $\mathrm{m}$ & 20 \\
Normal pressure angle & $\alpha$ & 0 & 2 \\
Helix angle & $\beta$ & $\mathrm{mm}$ & 0
\end{tabular}


Fig. 2 Production route and experimental set-up of the different test gear variants
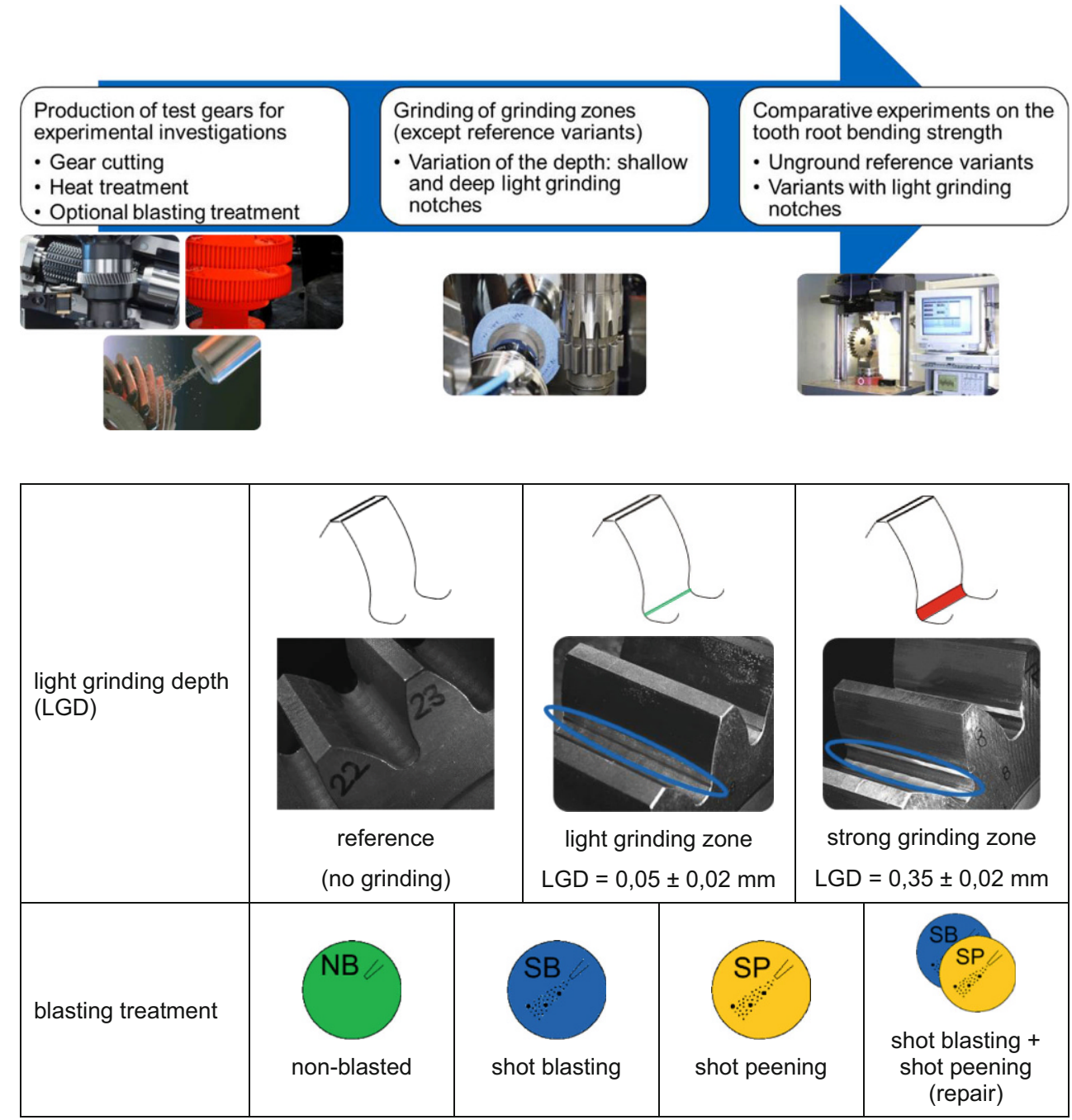

Fig. 3 Variation of light grinding depth and blasting treatment
There are three different variants concerning the blasting treatment: non-blasted, mechanical cleaned by shot blasting (shot blasted) and shot peened. The process parameters for the blasting processes are documented in [22]. For the reference variants, there is no grinding applied on the tooth root area. The variants with different grinding zones are generated with the help of a specifically programmed gear grinding machine at the research facility. The grinding zones are differentiated by the newly defined light grinding depth (LGD). The light grinding depth characterizes the distance between the originally unground tooth root in the grinding zone and the deepest point of the grinding zone. The grinding depth was chosen as characteristic parameter, because the tooth root bending strength is significantly influenced by the grinding depth. Two different variants of light grinding depths are generated: light $(\mathrm{LGD}=0.05 \pm 0.02 \mathrm{~mm})$ and strong $(\mathrm{LGD}=0.35 \pm 0.02 \mathrm{~mm})$ grindings. The grinding depth is directly proportional to the length of the grinding zone in tooth height direction. A light grinding depth will lead to a short length of the grinding zone in the height direction, a strong grinding depth will lead to a long length of the grinding zone in the tooth height direction. All grinding zones are positioned in the area of the point of contact of the $30^{\circ}$-tangent with the tooth root. For the variant reproducing a repair process, the gears are shot blasted after the heat treatment, a grinding zone is applied and for the actual repair the test gears are eventually shot peened. Fig. 3 shows the variations of the light grinding depth and the blasting treatment. A comprehensive documentation of the grinding parameters and the geometrical parameters of the generated grinding zones can be found in [22].

Within the research project, additional gear sizes and grinding zones were investigated regarding their influence on the tooth root bending strength. The experimental setup and the analysis of the investigations were corresponding to the approach presented in this paper. Test gears with a normal module of $\mathrm{m}_{\mathrm{n}}=3 \mathrm{~mm}$ and $8 \mathrm{~mm}$ were investigated and showed a comparable behaviour concerning the influence of the grinding zones. Further grinding zones with 
Fig. 4 Pulsator test rig with exemplary test gear
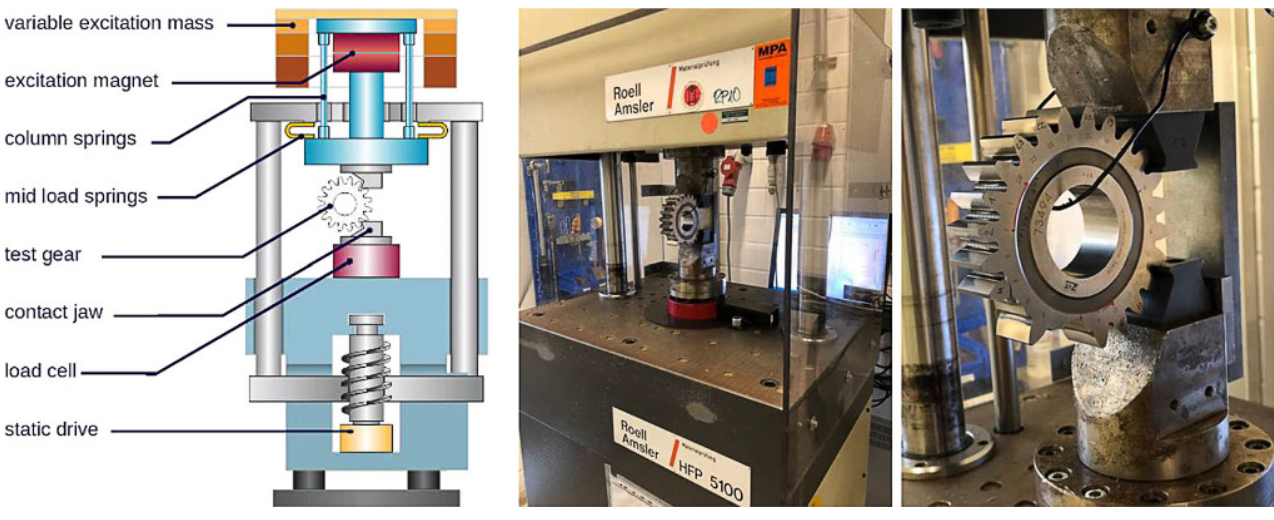

a smaller width of one third of the flank width and a position in the center or at one end of the tooth flank were applied. The different grinding zones showed a comparable influence on the tooth root bending strength, with the main influence parameter being the grinding depth. The results of the additional investigations will be subject to an upcoming publication.

\subsection{Test rig}

The bending fatigue tests are carried out by means of an electro-magnetic pulsating test rig as shown in Fig. 4 and described in the following according to [5]. The test rig consists of a machine frame, which incorporates the test device, load cell and test gear. The pulsating load is generated by a dynamic actuator, which is connected to a dynamic spring by an exciting magnet. The exciting magnet is directly connected to the pulsating crossbeam by two-rod springs. The test gears are symmetrically clamped and tested over four teeth between two jaws. The exact position of the test gears in relation to the clamp jaws, i.e. the exact angle and point of load incidence, is adjusted by means of a special jig. Helix angle deviations are compensated by means of a precision adjustment, so that a uniform load distribution across the whole face width can be assumed. The test gear is friction-locked between both jaws, therefore an underload is needed, which was always lower than $10 \%$ of the test load. The test runs are stopped after $6 \cdot 10^{6}$ load cycles. For each variant, the tooth root bending strength is derived from at least 22 single stage Wöhler tests in the area of limited and fatigue life. The test runs and the analysis of the results is conducted according to FVA Information Sheet 0/5 [1].

\section{Results of the experimental investigations}

The results of the experimental investigations as well as accompanying residual stress measurements are listed in the following. The calculated tooth root bending strength numbers were determined according to ISO 6336 and are related to the respective reference variant without a grinding application. Due to the experimental nature of the investigations, tooth root bending strength results within a scattering range of $\pm 5 \%$ are regarded as comparable. Table 2 shows the nominal stress numbers regarding bending and an approximate classification of the corresponding material quality grade of the reference variants.

Fig. 5 shows the relative tooth root bending strength of the non-blasted test gear variants.

The test results show, that there is no influence of light or strong grinding zones on the tooth root bending strength of non-blasted gears. The tooth root bending strength numbers of the variants with the light and strong grinding zones are comparable to the reference variant. Approximated numerical simulations indicate an increase of the occurring stress of $5-15 \%$ depending on the execution of the grinding zones. The experimental investigations do not show a reduction of the tooth root bending strength due to the notchincreased occurring stress. This leads to the conclusion, that the simulated stress increase alone is not decisive for the resulting bending strength. It is assumed that the geometrical stress-increasing notch-effects are compensated by further influences. Further influences in the grinded area include an improved local surface roughness, a grinded-off intergranular oxidation and additional compressive residual stresses due to the grinding in the tooth root area. Fig. 6 shows the residual stress depth profiles of the non-blasted test gear

Table 2 Nominal stress numbers regarding bending of the reference variants

\begin{tabular}{lll}
\hline Blasting treatment & Nominal stress number (bending) $\sigma_{\text {Flim }}$ acc. to ISO 6336 [10] & Material quality grade acc. ISO 6336-5 \\
\hline Non-blasted reference variant & $403 \mathrm{~N} / \mathrm{mm}^{2}$ & $\approx \mathrm{MQ} \mathrm{c})$ \\
Shot blasted reference variant & $547 \mathrm{~N} / \mathrm{mm}^{2}$ & $\approx \mathrm{ME}$ \\
Shot peened reference variant & $695 \mathrm{~N} / \mathrm{mm}^{2}$ & $>\mathrm{ME}$
\end{tabular}


Fig. 5 Relative tooth root bending strength of the non-blasted test gear variants

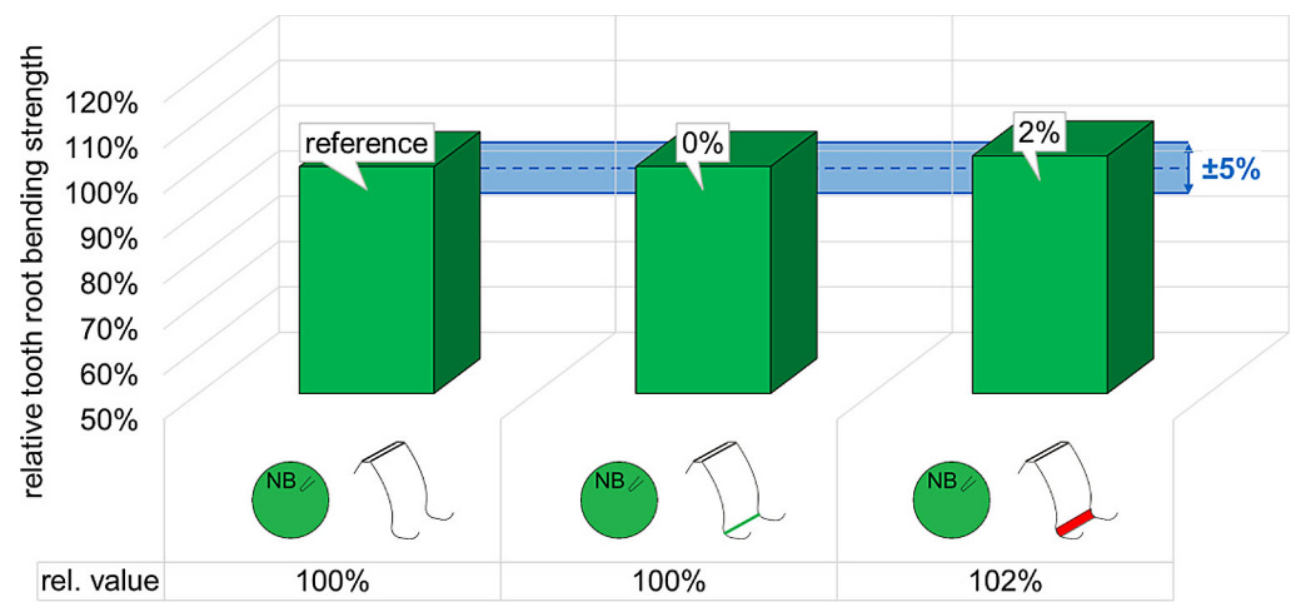

depth in $\mathrm{mm}$

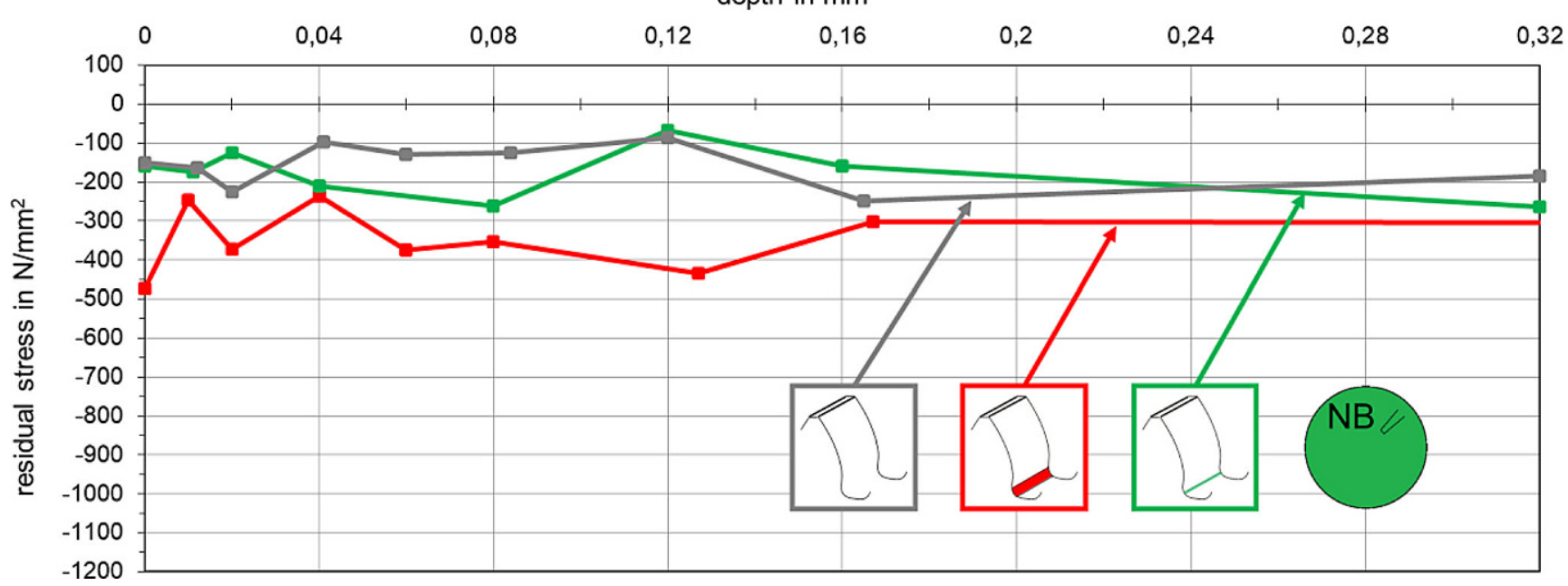

Fig. 6 Residual stress depth profiles of the non-blasted test gear variants

variants. The residual stress depth profiles were measured in the area of the grinding zones.

Within typical measuring scattering, all depth profiles show a comparable and steady course. The compressive residual stresses for the test gears with a strong grinding zone are constantly superior which correlates with the slightly increased tooth root bending strength compared to the reference variant. The slightly increased compressive residual stresses counteract notch-increased occurring stresses. The depth profile of the residual stresses with a strong grinding zone shows an increased compressive residual stress for the first measurement point which correlates with the theory of shallow compressive residual stresses being introduced by grinding. The depth profile for the light grinding zone does not show increased compressive residual stresses, which matches the weaker impact of the light grinding compared to the strong grinding.

Fig. 7 shows the relative tooth root bending strength of the shot blasted test gear variants.
The test results show, that the effect of grinding zones on the tooth root bending strength of shot-blasted gears depends on the depth of the grinding. The tooth root bending strength of test gears with light grinding zones is comparable to the reference test gears. The test gears with strong grinding zones show a significant reduction of the tooth root bending strength compared to the reference test gears. The tooth root bending strength of the shot-blasted test gears with strong grinding zones is comparable to the non-blasted test gears. It is assumed, that the tooth root bending strength numbers of the two different variants coincide due to comparable residual stress states below the surface. Fig. 8 shows the residual stress depth profiles of the shot blasted test gear variants.

The reference test gear variant shows a typical residual stress depth profile characterized by high compressive residual stresses at the surface and in the near-surface material layer with a decrease in deeper material depths to values comparable with non-blasted test gears. The residual stress depth profile of the test gear variant with the light grinding 
Fig. 7 Relative tooth root bending strength of the shot blasted test gear variants and comparison with the tooth root bending strength of the non-blasted reference variant

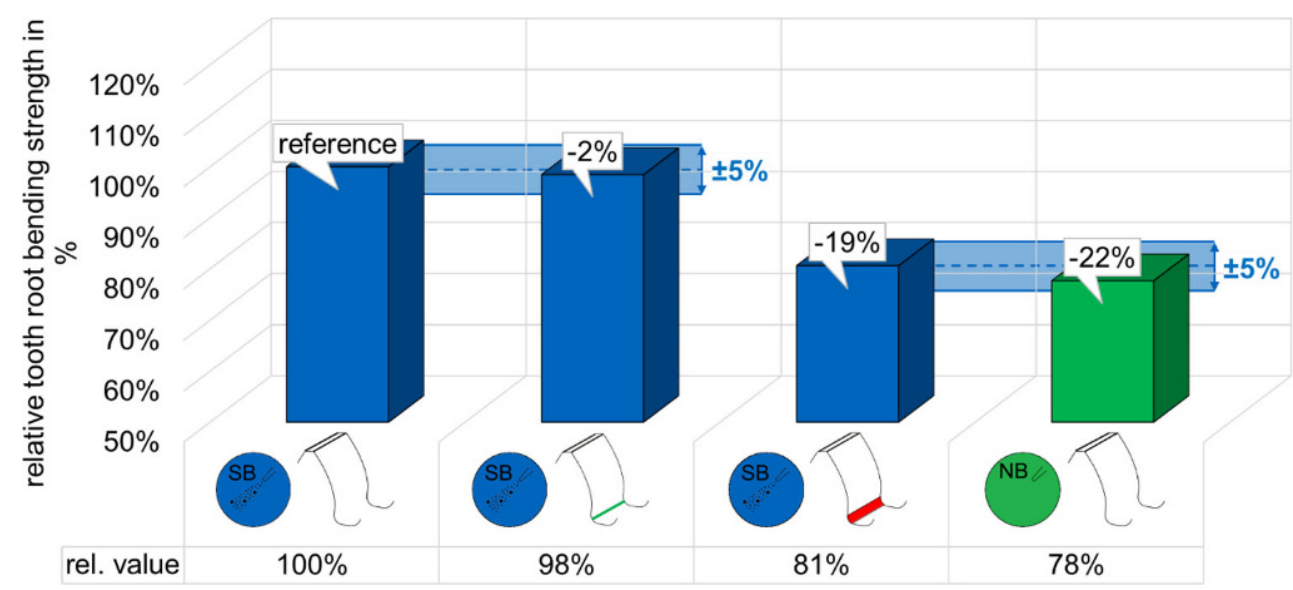

depth in $\mathrm{mm}$

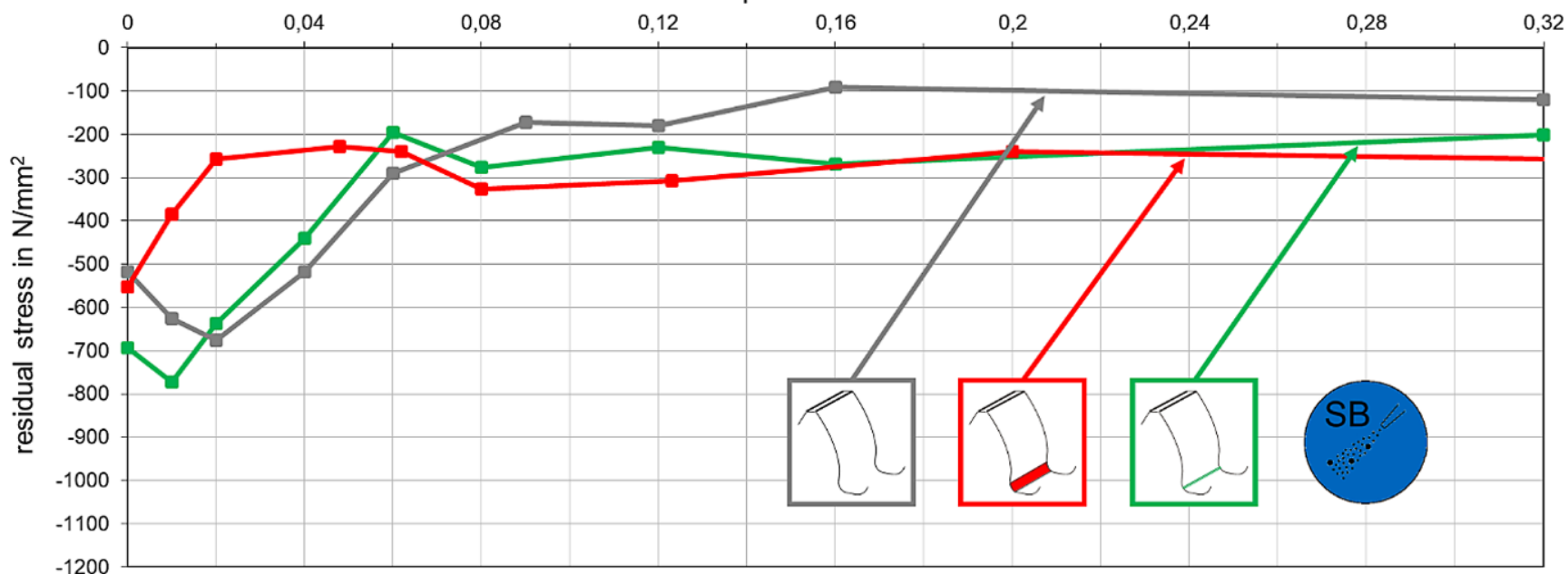

Fig. 8 Residual stress depth profiles of the shot blasted test gear variants

zones shows a comparable course as the reference variant which correlates with the comparable tooth root bending strength. The test gear variant with the strong grinding zones shows a clearly different residual stress depth profile which correlates with the strong effect on the tooth root bending strength. Only directly at the surface and in a depth of $0.01 \mathrm{~mm}$ increased residual stresses were measured but in the depth range of $0.02-0.06 \mathrm{~mm}$ the compressive residual stresses strongly decrease. The reduced tooth root bending strength of this variant is comparable to the non-blasted test gear variant. The measurements confirm the assumption that the two different variants coincide due to their similar residual stress state, especially in the near surface layer.

Fig. 9 shows the relative tooth root bending strength of the shot peened test gear variants.

The strength reducing influence of stronger grinding zones on the tooth root bending strength of the shot peened test gear variant is similar as for the shot blasted test gear variants. The decreased tooth root bending strength again is comparable to the non-blasted reference variant.
The comparable values correlate with the presumption of the same mechanism decreasing the compressive residual stresses near the surface and thus decreasing the tooth root bending strength. The repair variant was initially shot blasted, afterwards a strong grinding zone was applied and lastly the tooth root area was shot peened. The idea was to repair the test gear variant by adding compressive residual stresses via the shot peening and thus re-increasing the tooth root bending strength. The test results show, that the tooth root bending strength is increased but neither reaches the value of the shot peened reference nor shot blasted reference variant but exceeds the bending strength number of the non-blasted reference variant. It is possible that a stronger increase of the tooth root bending strength could be achieved with optimized blasting parameters such as more adequate shot material, ejection speed and covering. Fig. 10 shows the residual stress depth profiles of the shot peened test gear variants. The shot peened test gear variant with strong grinding zones and no repair was not measured within this investigation. 
Fig. 9 Relative tooth root bending strength of the shot peened test gear variants and comparison with the tooth root bending strength of the non-blasted reference variant
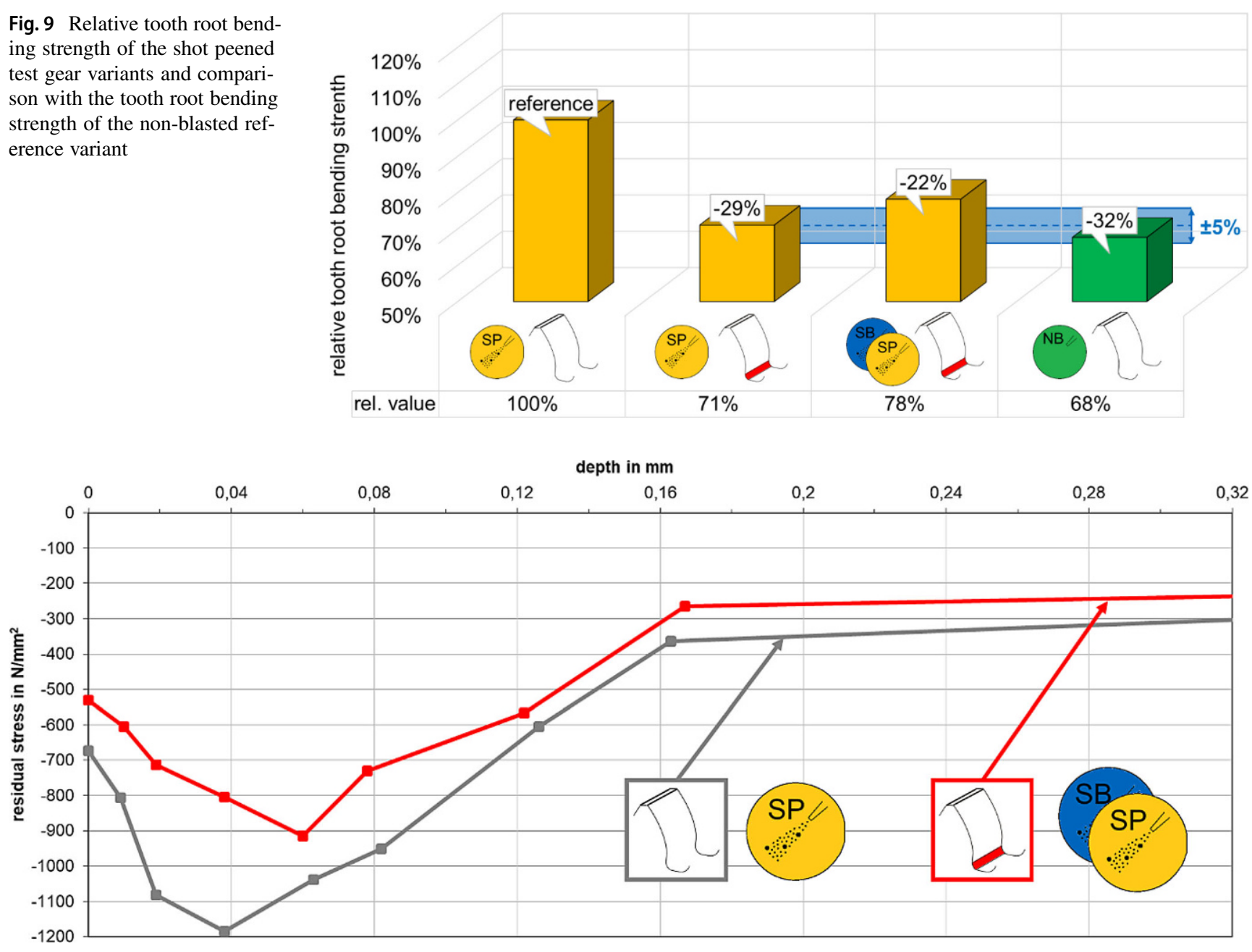

Fig. 10 Residual stress depth profiles of the shot peened test gear variants

The reference variant shows a typical depth profile for a shot peened test gear: Compared to a shot blasted variant, increased compressive residual stresses affect deeper material depths. The repair variant shows that with the chosen shot peening parameters, it was not possible to establish the residual stress state of the shot peened reference variant. The lower compressive residual stresses of the repair variant correlate with a decreased tooth root bending strength. Additional influences on the tooth root bending strength such as improved surface roughness, removal of intergranular oxidation or possible reduction of surface hardness are assumed but were not explicitly measured within these investigations. Corresponding experimental investigations and measurements on the additional influences as well as elaborate simulations are to be conducted to fully understand, differentiate and quantify the various parameters influencing the tooth root bending strength.

\section{Conclusion and summary}

The results of the experimental investigations show that grinding zones can have diverse influences on the tooth root bending strength of case carburized gears with different blasting treatments. The experimental investigations were conducted within a research project, in whcih further gear sizes, grinding zones and material properties were investigated. All results and variants are comprehensively documented in the final report [22]. The results presented here are a representative selection to show the main findings of the research project. Fig. 11 shows the summarized experimental results of the tooth root bending strength for the investigated test gear variants.

The following conclusive statements can be derived from the experimental investigations:

- Non-blasted gears do not show changes regarding the tooth root bending strength with regard to the light or strong grinding zones applied within this investigation. 
Fig. 11 Results for the tooth root bending strength of the investigated test gear variants

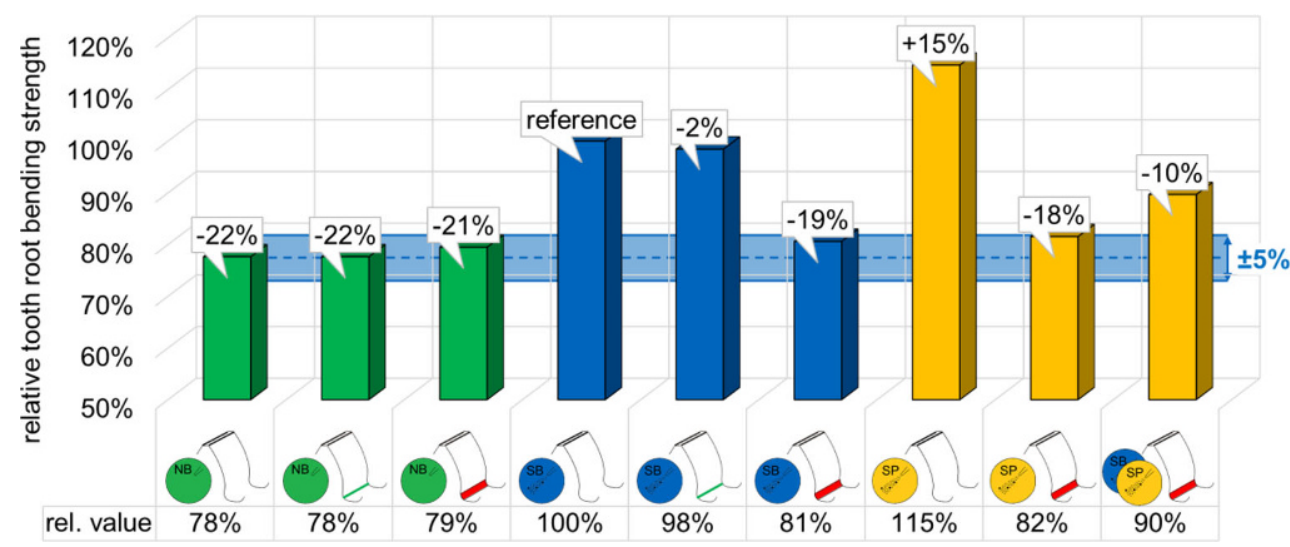

- Shot blasted (mechanical cleaned) gears show no change in the tooth root bending strength for light grinding zones (grinding application does not significantly alter the original residual stress state in the tooth root area).

- Shot blasted (mechanical cleaned) gears show a reduction of the tooth bending strength of up to $20 \%$ with regard to strong grinding zones (grinding application does significantly alter the original residual stress state in the tooth root area).

- Shot peened gears show a behavior similar to that of shot blasted gears with reductions of the tooth root bending strength of up to $30 \%$.

- Shot peening the strong grinding zones as a repair measure can increase the reduced tooth root bending strength again. For the investigated test gears, the resulting tooth root bending strength was below the shot blasted reference variant.

The results of this paper help to evaluate the influence of grinding zones on the tooth root bending strength of case carburized gears more precisely compared to the generalized reductions of current standards and classifications. The results can be incorporated in standards such as DIN 3390 [4] as well as ISO 6336 [10] and can be applied in the field of industrial practice. The findings may help to reduce the current loss of time and cost caused by uncertainties regarding grinding zones.

Funding Open Access funding enabled and organized by Projekt DEAL.

Conflict of interest K.J. Winkler, T. Tobie and K. Stahl declare that they have no competing interests.

Open Access This article is licensed under a Creative Commons Attribution 4.0 International License, which permits use, sharing, adaptation, distribution and reproduction in any medium or format, as long as you give appropriate credit to the original author(s) and the source, provide a link to the Creative Commons licence, and indicate if changes were made. The images or other third party material in this article are included in the article's Creative Commons licence, unless indicated otherwise in a credit line to the material. If material is not included in the article's Creative Commons licence and your intended use is not permitted by statutory regulation or exceeds the permitted use, you will need to obtain permission directly from the copyright holder. To view a copy of this licence, visit http://creativecommons.org/licenses/by/4. $0 \%$

\section{References}

1. Bergmann C, Rettig H, Hück M, Matt P, Niemann G, Winter H, Stahl K, Tobie T (1999) Ergänzungen zu FVA-Merkblatt Nr. 0/5 Empfehlung zur Vereinheitlichung von Pulsatorversuchen zur Zahnfußtragfähigkeit von vergüteten und gehärteten Zylinderrädern ([Recommendation for the standardization of pulsator tests on the tooth root bending strength of quenched and tempered cylindrical gears])

2. Chatterjee-Fischer R (1973) Beispiele für durch Wärmebehandlung bedingte Eigenspannungen und ihre Auswirkungen [Examples of residual stresses caused by heat treatment and their effects]. HTM 28:276-288

3. Det Norske Veritas (2015) DNVGL-CG-0036 Calculation of gear rating for marine transmissions, classification note (DNVGL-CG0036)

4. Deutsches Institut für Normung e. V. (DIN) (1987) Tragfähigkeitsberechnung von Stirnrädern [Calculation of load capacity of cylindrical gears] German Standard (DIN 3990). Beuth, Berlin

5. Fuchs D, Schurer S, Tobie T, Stahl K (2019) A model approach for considering nonmetallic inclusions in the calculation of the local tooth root load-carrying capacity of high-strength gears made of high-quality steels. Proc Inst Mech Eng Part C J Mech Eng Sci 233(21-22):7309-7317. https://doi.org/10.1177/ 0954406219840676

6. Güntner C, Tobie T, Stahl K (2017) Influences of the residual stress condition on the load carrying capacity of case hardened gears. In: AGMA 2017 Fall Technical Meeting, pp 328-344

7. Häfele P, Issler L, Ruoß H (2003) Festigkeitslehre - Grundlagen [Strength of materials - Basics]. Springer, Berlin, Heidelberg, New York

8. Härterei Reese (2021) Abbildung eines Stirnrads großer Baugröße beim Einsatzhärten [Illustration of a large-size cylindrical gear during case hardening]

9. Hirsch T (1983) Untersuchungen zur Zahnfußtragfähigkeit kugelgestrahlter Zahnräder [Investigations on the tooth root load carrying capacity of shot peened gears]. FVA-Heft, vol 126. Forschungsvereinigung Antriebstechnik e. V., Frankfurt a.M.

10. International Organization for Standardization (ISO) (2019) Calculation of load capacity of spur and helical gears, International Standard (ISO 6336). Beuth, Berlin 
11. Kloos KH, Kaiser B (1990) Fertigungsinduzierte Eigenspannungen [Manufacturing induced residual stresses]. HTM 45(6):356-366

12. Kratzer D, Dobler F, Tobie T, Hoja S, Steinbacher M, Stahl K (2019) Effects of low-temperature treatments on surface hardness, retained austenite content, residual stress condition and the resulting tooth root bending strength of case-hardened 18CrNiMo7-6 gears. Proc Inst Mech Eng Part C J Mech Eng Sci 233:7350-7357. https://doi.org/10.1177/0954406219846160

13. Laue S, Bomas H, Hoffman F, Mayr P (2004) Untersuchungen zum Einfluss des Randschichtzustandes auf die Schwingfestigkeit einsatzgehärteter Proben aus dem Stahl $16 \mathrm{MnCr} 5$ [Investigations on the influence of the surface condition on the fatigue strength of case-hardened specimens made of $16 \mathrm{MnCr} 5$ steel]. HTM 59(3): 199-210

14. Lombardo S (2014) Einfluss von verschiedenen Carbonitrierverfahren auf die Zahnfuß- sowie Zahnflankentragfähigkeit von Stirnrädern [Influence of different carbonitriding processes on the tooth root as well as the flank strength of spure gears]. Dissertation, Technische Universität München

15. Lombardo S, Stenico A, Tobie T, Höhn B-R (2009) Influence of residual stresses on tooth root bending strength of case hardened gears. MPT. https://doi.org/10.1299/jsmeimpt.2009.333

16. Löwisch G (1994) Zuordnung von Werkstoffkennwerten zu Bauteileigenschaften von einsatzgehärteten und carbonitrierten Zahnrädern [Assignment of material properties to component properties of case-hardened and carbonitrided gears]. FVA-Heft, vol 414. Forschungsvereinigung Antriebstechnik e. V., Frankfurt
17. Macherauch E, Wohlfahrt H, Wolfstieg U (1973) Zur zweckmäßigen Definition von Eigenspannungen [For the purposeful definition of residual stresses]. HTM 28(3):201-211

18. Niemann G, Winter H, Höhn B-R (2003) Getriebe allgemein, Zahnradgetriebe - Grundlagen, Stirnradgetriebe [General transmissions, gearboxes - fundamentals, spur gears]. Maschinenelemente [Machine elements], vol 2. Springer, Berlin, Heidelberg, New York

19. Stenico A (2007) Werkstoffmechanische Untersuchungen zur Zahnfußtragfähigkeit einsatzgehärteter Zahnräder [Material mechanical investigations on the tooth root bending strength of casehardened gears]. Dissertation, Forschungsstelle für Zahnräder und Getriebebau (FZG), Technische Universität München

20. Weigand U (1999) Werkstoff- und Wärmebehandlungseinflüsse auf die Zahnfußtragfähigkeit [Material and heat treatment influences on tooth root bending strength]. Dissertation, Technische Universität München

21. Wohlfahrt H (1984) The influence of peening conditions on the resulting distribution of residual stress. In: Second International Conference on Shot Peening, pp 316-331

22. Winkler KJ, Tobie T, Stahl K (2019) Einflüsse angeschliffener Zahnfußrundungen auf die Zahnfußtragfähigkeit einsatzgehärteter Stirnräder [Influences of ground tooth root fillets on the tooth root load carrying capacity of case-hardened cylindrical gears] (AiFAbschlussbericht und FVA-Sachstandsberichte) 